http://heanoti.com/index.php/hn



RESEARCH ARTICLE

URL of this article: http://heanoti.com/index.php/hn/article/view/hn30106

\title{
Strawberry Extract as a Tooth Stain Remover
}

\author{
Ita Yulita ${ }^{1(\mathrm{CA})}$, Ita Astit Karmawati², Rahaju Budiarti ${ }^{3}$ \\ ${ }^{1(\mathrm{CA})}$ Department of Dental Nursing, Health Polytechnic of Jakarta I, Indonesia; iyulita67@yahoo.com \\ (Corresponding Author) \\ ${ }^{2}$ Department of Dental Nursing, Health Polytechnic of Jakarta I, Indonesia; itaastit@yahoo.com \\ ${ }^{3}$ Department of Dental Nursing, Health Polytechnic of Jakarta I, Indonesia; rahayu.budiarti13@gmail.com
}

\begin{abstract}
This study aimed to compare the effectiveness of strawberry extract with $100 \%, 75 \%, 50 \%$ and $25 \%$ concentration in cleaning the extrinsic stain on the teeth. The sample of the study was 32 permanent anterior teeth that were already extracted, consisting of each 16 maxillary and mandibular anterior teeth and all samples have an extrinsic stain. The samples were randomly divided into 4 groups, each group consisting of 8 teeth was treated by applying the strawberry extract with the concentrations of $100 \%, 75 \%, 50 \%$ and $25 \%$. After 5 minutes, the teeth were rinsed and dried. The study was conducted in vitro for five consecutive days with twice treatment daily. Intensity Score and Extension Score of the stain were measured using the Lobene Stain Index. All samples experienced a decrease in both the Intensity and Extension Scores, the largest decrease in Intensity and Extension Score were obtained from strawberry extracts with concentration of $100 \%$. The significant decrease in the Intensity Score occurs on the third day and continues until the fourth and fifth days, while the significant decrease in the Extention Score occurs on the fourth day and continues until the fifth day. The four group of the strawberry extract concentrations gave a decrease in the score, which distinguishes the treatment frequency. The higher the concentration, the frequency would be less in lowering stain score, whereas at low concentration the decrease of score require more frequency.
\end{abstract}

Keywords: Extrinsic stain, Strawberry extract

\section{INTRODUCTION}

The neatness of the set and the color of the teeth becomes so important so that there arises what is called "aesthetic dentistry", which now begins to gain attention, both by the public and the dentist. One of them is teeth whitening. Although the color of a person's teeth varies, but striking different colors will be very disturbing. The causes of discoloration of the teeth are various that can generally be classified in extrinsic (external) and intrinsic (internal) causes. Physiological tooth discoloration may occur with age, because dentin (the hard layer that protects the tooth nerve) may become thicker due to the deposits of the secondary dentin and the reparative dentin so that resulting in the discoloration of the teeth. Pathological changes in the color can be extrinsic and intrinsic. Extrinsic color changes may be caused by deposits that occur on a tooth surface, whereas intrinsic color changes are caused by factors within the dental tissue or pulp tissue ${ }^{(1),(2)}$.

Teeth whitening can be done in dental practice that includes two things, eliminating extrinsic colors and intrinsic colors. Extrinsic whitening can be done either mechanically or chemically, which is specifically done by the dentist, termed as in office bleaching ${ }^{(3),(4)}$. Tooth bleaching is usually done to remove yellow or dull colored teeth due to scraps of food such as coffee, chocolate, cigarettes, medicines or some other color changes due to structural changes in the teeth. Tooth whitening is also done to restore the color of the teeth into a natural color or make it whiter ${ }^{(2)}$. The chemicals used as a teeth whitener are Hydrogen Peroxide $\left(\mathrm{H}_{2} \mathrm{O}_{2}\right)$, Carbamide Peroxide $\left\{\mathrm{CO}\left(\mathrm{NH}_{2}\right) 2 . \mathrm{H}_{2} \mathrm{O}_{2}\right\}$ and Sodium Perborate $\left(\mathrm{NaBO}_{3} .4 \mathrm{H}_{2} \mathrm{O}\right)^{(5)}$.

Strawberry is a herbaceous fruit plants found first in Chile, America. One species of strawberry plants namely Fragaria chiloensis L spread to various countries of America, Europe and Asia. Furthermore, other species, namely F. vesca $L$ is more widespread than other species. This strawberry is also the first one that enters Indonesia. Aside from its vitamin and mineral content, strawberries also contain ellagic acid and malic acid ${ }^{(6),(7)}$. The malic acid contained in the strawberries acts as a substance that will scrape and remove some stains on the tooth surface. By 
chewing strawberries every day can help to nourish the mouth, such as a teeth whitening, eliminate bad breath, and make the breath becomes more fresh. Parts of strawberry plants that can be used to whiten teeth are fruit and leaves. Malic acid is said to be involved in the erosion process. These acids can bind calcium in the tooth enamel and cause enamel crystal porosity which has an impact on tooth erosion which will reduce the hardness of the tooth surface ${ }^{(7)}$

The research on the effect of strawberries on a discoloration of the teeth with extrinsic stain in order to know the effect of strawberries in whitening and/or cleaning the teeth with extrinsic stain, which was performed on the 32 avulsed human teeth by smearing the teeth with the strawberry fine that was left for 5 minutes, then it was brushed and rinsed, which was carried out for 5 consecutive days with a frequency of 3 times a day, concluded that there was a discoloration of the teeth and or a change in the thickness of the extrinsic stain between before and after being treated with strawberries ${ }^{(8)}$.

\section{METHODS}

\section{Sample Selection}

This study was an in vitro study using 32 avulsed permanent teeth, with inclusion criteria that were 16 maxillary and 16 mandibular anterior teeth which have extrinsic stains.

\section{Treatment Implementations}

The sample was divided into 4 groups with the total of each group was 8 teeth. Each group was treated with 4 groups of the concentrations of strawberry extract that were $100 \%, 75 \%, 50 \%, 25 \%$. The fresh strawberries were crushed using a food processor and filtered to get the extract. To get the concentration of $75 \%, 50 \%$ and $25 \%$, the strawberry extracts were diluted with aquadest, while the $100 \%$ concentration was obtained from the pure extract without a mixture.

The applications of the strawberry extracts were performed on the entire teeth surface by applying the strawberry extract with the concentrations of $100 \%, 75 \%, 50 \%$, and $25 \%$ for 4 groups of teeth respectively. Left it for 5 minutes, cleaned it by rubbing the surface of the tooth with a cotton pellet, rinsed and dried the tooth using the three way syringe. The treatments were done twice a day.

The stain score recording was performed before and after the teeth were smeared with the strawberry extracts, with the measurements used the Lobene Stain Index ${ }^{(9)}$.

\section{Statistical Analysis}

Processing and data analysis was performed using Statistical Package for the Social Sciences (SPSS) with descriptive analysis for dependent variable that was extrinsic stain and multivariate score used the General Linear Model Repeated Measure (GLMRM) to test the difference of extrinsic stain score before and after the application of extract strawberries, and the concentration of the most effective strawberry extract in stain cleaning.

\section{RESULTS}

The decreases of the stain index in the Intensity Score, Extension Score and Combined Score on all of the samples that were treated with the different concentrations of the strawberry extracts $(100 \%, 75 \%, 50 \%, 25 \%)$ are seen in Table 1, 2 and 3.

Table 1. Distribution of the Mean of the Intensity Score Before and After Treatments Based on the Strawberry Extract Concentrations

\begin{tabular}{ccccccc}
\hline $\begin{array}{c}\text { Concentration of } \\
\text { Extract }(\%)\end{array}$ & $\begin{array}{c}\text { Intensity Score } \\
\text { (Before Treatment) }\end{array}$ & \multicolumn{5}{c}{$\begin{array}{c}\text { Intensity Score After Treatment } \\
\text { Day- }\end{array}$} \\
\cline { 3 - 7 } & & 1 & 2 & 3 & 4 & 5 \\
\hline 25 & 2.88 & 2.88 & 2.63 & 2.50 & 2.25 & 1.75 \\
50 & 2.75 & 2.75 & 2.63 & 2.25 & 1.88 & 1.63 \\
75 & 2.75 & 2.25 & 2.00 & 1.88 & 1.13 & 1.00 \\
\hline 100 & 3.00 & 2.75 & 2.63 & 2.38 & 1.88 & 1.13 \\
\hline
\end{tabular}


Table 2. Distribution of the Mean of the Extension Score Before and After Treatments Based on the Strawberry Extract Concentrations

\begin{tabular}{ccccccc}
\hline $\begin{array}{c}\text { Concentration of } \\
\text { Extract (\%) }\end{array}$ & $\begin{array}{c}\text { Extention Score } \\
\text { (Before Treatment) }\end{array}$ & \multicolumn{5}{c}{$\begin{array}{c}\text { Extention Score After Treatment } \\
\text { Day- }\end{array}$} \\
\cline { 3 - 7 } & & 1 & 2 & 3 & 4 & 5 \\
\hline 25 & 3.88 & 3.88 & 3.50 & 3.00 & 2.75 & 2.13 \\
50 & 3.00 & 2.88 & 2.75 & 2.50 & 2.13 & 1.63 \\
75 & 2.38 & 2.38 & 2.38 & 2.25 & 1.38 & 1.13 \\
\hline 100 & 3.63 & 3.63 & 3.38 & 3.38 & 2.13 & 1.63 \\
\hline
\end{tabular}

Table 3. Distribution of the Mean of the Combined Score Before and After Treatments Based on the Strawberry Extract Concentrations

\begin{tabular}{ccccccc}
\hline $\begin{array}{c}\text { Concentration of } \\
\text { Extract }\end{array}$ & $\begin{array}{c}\text { Combined Score } \\
\text { (Before Treatment) }\end{array}$ & \multicolumn{5}{c}{$\begin{array}{c}\text { Combined Score After Treatment } \\
\text { Day- }\end{array}$} \\
\cline { 3 - 6 }$(\%)$ & & 1 & 2 & 3 & 4 & 5 \\
\hline 25 & 6.76 & 6.76 & 6.13 & 5.50 & 5.00 & 3.88 \\
50 & 5.75 & 5.63 & 5.38 & 4.75 & 4.01 & 3.26 \\
75 & 5.13 & 4.63 & 4.38 & 4.13 & 2.51 & 2.13 \\
\hline 100 & 6.63 & 6.38 & 6.01 & 5.76 & 4.01 & 2.75 \\
\hline
\end{tabular}

\section{DISCUSSION}

The results showed that in all samples treated with strawberry extracts of varying concentrations (100\%, $75 \%, 50 \%, 25 \%$ ) decreased the stain index in both the Intensity Score and the Extention Score, which ultimately also decreased the Combined Scores. The greatest decrease in the Intensity Scores and the Extention Score was found in the group of samples treated with $100 \%$ strawberry extract concentration. The significant decrease in the Intensity Score occurs on the third day and continues until the fourth and fifth days, while the significant decrease in the Extention Score occurs on the fourth day and continues until the fifth day. This was in line with the previous research conducted by Karmawati et al. (2015), where the applications of crushed strawberries conducted for 5 consecutive days can significantly reduce the stain score ${ }^{(10)}$.

Strawberry extracts with the $100 \%$ and $75 \%$ concentrations is enough given until day 5 (to get Intensity Score $=1$ ), while strawberry extract with concentrations of $50 \%$ and $25 \%$ takes longer to reach Intensity Score = 1. Strawberry extracts with concentrations $100 \%$ and $75 \%$ are enough to be given until the fifth day (to get Extension Score <2), while the $50 \%$ and $25 \%$ strawberry extracts takes a longer time to reach the Extention Score $<2$.

The research of Asmawati et al. conducted to see changes in tooth enamel structure after the strawberry gel application found that there was no significant effect between the duration of application time and changes in tooth enamel structure ${ }^{(11)}$.

\section{CONCLUSIONS}

The four group of the strawberry extract concentrations gave a decrease in the score, which distinguishes the treatment frequency. The higher the concentration will be less frequency in lowering stain score, whereas at low concentration the decrease in the score require more frequency.

\section{REFEENCES}

1. Sundoro EH. About the Science of Dental Conservation (Serba Serbi Ilmu Konservasi Gigi). Jakarta: UIPress; 2005.

2. Rodrigues FT, Serro AP, Polido M, Ramalho A, Figueiredo-Pina CG. Effect of Bleaching Teeth with Hydrogen Peroxide on the Morphology, Hydrophilicity, and Mechanical and Tribological Properties of The Enamel. Wear. 2017;374-375:21-28. http://dx.doi.org/10.1016/j.wear.2016.11.001

3. Nakamura T, Saito O, Ko T, Maruyama T. The Effect of Polishing and Bleaching on The Colour of Discoloured Teeth in Vivo. J. Oral Rehabil. 2001;28(11):1080-1084.

4. Hatrick CD, Eakle WS, Bird WF. Dental Material: Clinical Application for Dental Assistants and Dental Hygienists. St. Louis, Missouri: Elsevier; 2003.

5. Ito Y, Momoi Y. Bleaching Using 30\% Hydrogen Peroxide and Sodium Hydrogen Carbonate. Dental 
Material Journal. 2011;30(2):193-198.

6. Margaretha J, Rianti D, Meizarini A. Effect of Strawberry Paste and Carbamide Peroxide Gel 10\% Towards the Brightness Enamel Tooth. Material Dental Journal. 2009;1(1):16-20.

7. Larasati DM, Firsty KN, Yogiartono M. Effectiveness of Ellagic Acid that Contains in Strawberry for Acrylic Discoloration. Asia Pacific Dental Students Journal. 2012;3(2):1-9.

8. Karmawati IA, Yulita I, Budiarti R. Effect of Strawberries on Discoloration of Teeth Undergoing Extrinsic Stain (Pengaruh Buah Stroberi Terhadap Perubahan Warna Gigi yang Mengalami Extrinsic Stain). Jakarta: Poltekkes Kemenkes Jakarta I; 2014.

9. He T, Dunavent JM, Fiedler SK, Baker RA. A Randomized Clinical Study to Assess the Extrinsic Staining Profiles of Stannous- and Triclosan-containing Dentifrices. Am J Dent. 2010; Sep;23 Spec No B:22B - 26B

10. Karmawati IA, Budiarti R, Yulita I. The Influence of Strawberries on the Cleaning of Teeth with Extrinsic Stain in the Academic Community of Health Polytechnic of Jakarta I (Pengaruh Buah Stroberi Terhadap Pembersihan Gigi Dengan Extrinsic Stain Pada Civitas Akademika Poltekkes Kemenkes Jakarta I). Jakarta: Poltekkes Kemenkes Jakarta I; 2015.

11. Asmawati, et al. An Analysis of the Compounds of Dental Enamel after Application Strawberry Gel with Energy-Dispersive X-ray Spectroscopy (EDS). Journal of International Dental and Medical Research. 2018;11(2):656-662. 